\title{
SPring-8における構造生物学用理研ビームラインの開発
}

山本 雅貴·藤澤 哲郎·中迫 雅由・鈴木 昌世·宇留賀 朋哉

植木 龍夫・岩崎 準

理研・放射光構造生物学、大型放射光

理化学研究所では、棈造生物学研究を推進するための SPring-8 利用計画について検討を 行い、現在構造生物学用理研ビームラインの建設を進めている。本ビームラインでは、ダ イヤモンド結晶分光器を用いてアンジュレータ光を分岐することにより小角散乱ステーショ ンと蛋白質結晶構造解析ステーションで同時に使用することを想定している。

蛋白質結晶構造解析ステーションは、MAD法に最適化した設計を採用して、より簡便に 多くの蛋白質の未知構造を解明することを最大の目的にしている。

本実験ステーションでは、新たに同時に異なる 3 波長をもちいた回折強度測定が可能な " Trichromatic Concept " を考案した。今までのMAD法の実験では、異なる波長での回折强 度測定は、1つのモノクロメーターによる波長切り替えにより行っていたが、この方法で は波長やX線ビーム強度の再現性や安定性に問題があり、さらには1つの結晶で全波長 （ 3 波長以上）の回折強度測定を行うためには波長切り替えのためのデッドタイムが多く 必要であり、結晶のダメージも心配された。

" Trichromatic Concept "では、タンデムアンジュレータからの異なる 2 波長のアンジュレ ータ光から、トリクロメータと呼ばれるダイヤモンド結晶を用いた透過型の 3 波長分光器 により、吸収端近傍の 2 波長とリモートの合計 3 波長を同時に切り出し、ビームチョッパ ーにより時系列に従って 3 波長交互に回折強度測定に使用が可能である。これにより、分 光器や回折計のセッテングを変えることなく同じ結晶から 3 波長の回折強度が測定可能で あり、MAD法における回折強度測定系での系統誤差を最小化することが可能である。

\section{Protein Crystallography}

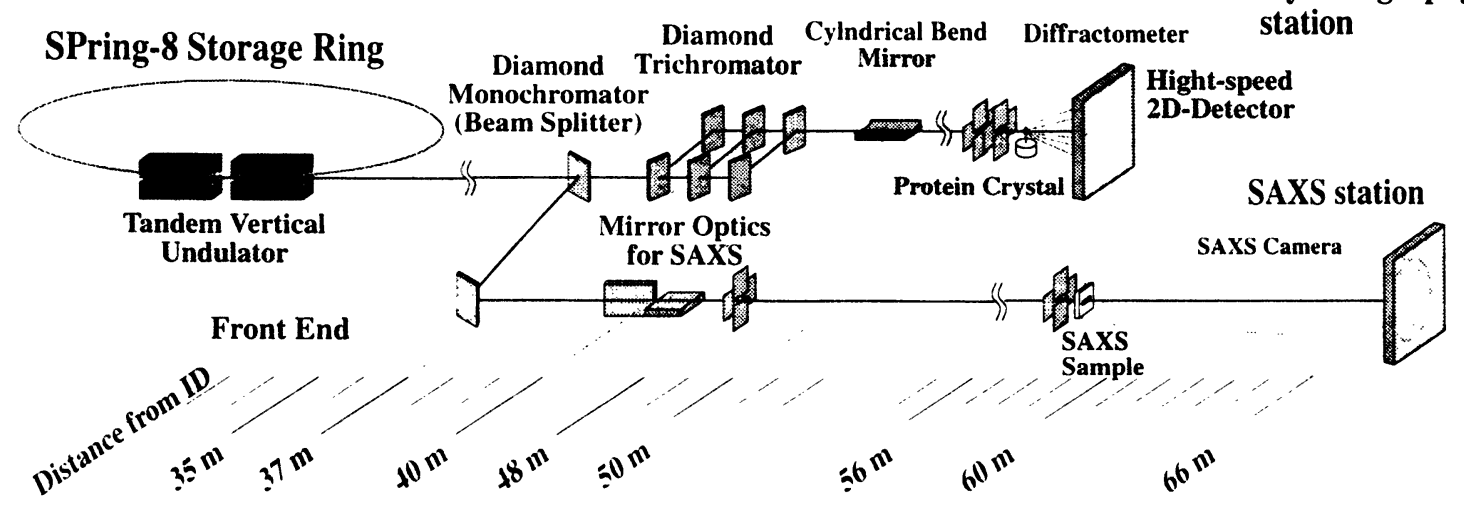

